\title{
Performance and Emissions of Sunflower, Rapeseed, and Cottonseed Oils as Fuels in an Agricultural Tractor Engine
}

\author{
Athanasios Balafoutis, ${ }^{1}$ Spyros Fountas, ${ }^{2}$ Athanasios Natsis, ${ }^{1}$ and George Papadakis ${ }^{1}$ \\ ${ }^{1}$ Department of Natural Resources \& Agricultural Engineering, Agricultural University of Athens, Iera Odos 75, 11855 Athens, Greece \\ ${ }^{2}$ Department of Agriculture Crop Production and Rural Environment, University of Thessaly, Fytoko street, 38446 N. Ionia, Greece
}

Correspondence should be addressed to Athanasios Balafoutis, thabalafoutis@hotmail.com

Received 20 July 2011; Accepted 18 August 2011

Academic Editors: M. S. Abdel-Mottaleb and C. Muraleedharan

Copyright (C) 2011 Athanasios Balafoutis et al. This is an open access article distributed under the Creative Commons Attribution License, which permits unrestricted use, distribution, and reproduction in any medium, provided the original work is properly cited.

\begin{abstract}
A comparative experimental investigation was conducted to evaluate the performance and exhaust emissions of an agricultural tractor engine when fueled with sunflower oil, rapeseed oil, and cottonseed oil and their blends with diesel fuel (20/80, 40/60 and 70/30 volumetrically). Tests were also carried out with diesel fuel to be used as a reference point. Engine power, torque, BSFC, thermal efficiency, $\mathrm{NO}_{x}$ and $\mathrm{CO}_{2}$ were recorded for each tested fuel. All vegetable oils resulted in normal operation without problems during the short-term experiments. The 20/80 blends showed unstable results, in comparison to higher oil content fuels. Power, Torque and BSFC were higher as oil content was increased in the fuel. Rapeseed oil fuels showed increased power, torque and thermal efficiency with simultaneous lower BSFC in comparison to the other two vegetable oils. Cottonseed oil fuels gave better engine performance than sunflower oil fuels. In all oil types, $\mathrm{NO}_{x}$ emissions were augmented when fuel oil percentage was increased. Cottonseed oil fuels led to higher $\mathrm{NO}_{x}$ emission increase compared to rapeseed oil fuels. $\mathrm{CO}_{2}$ emissions showed a tendency to be increased as the oil content was evolved. The highest $\mathrm{CO}_{2}$ emissions were given by cottonseed oil fuels, followed by rapeseed and sunflower oil.
\end{abstract}

\section{Introduction}

Nowadays, agriculture has been developed as an economical sector where mechanization plays a significant role in the final output. However, over the last 40 years, the doctrine has been the maximization of production without taking into account the energy input and its environmental impact. It is evident that agricultural tractors have been widely used for all agricultural practices with important fuel consumption, due to high power needs during field operations.

According to European Energy Agency [1], agricultural sector stands for only $3.7 \%$ in EU energy profile. This percentage is low in comparison to other energy consumers. However, the fact that agricultural tractors count for 90 $95 \%$ of total on field agricultural energy consumption [2] shows that total fossil fuel requirements for this purpose is significant. Therefore, measures on reducing fossil fuel consumption should be also adopted in this domain. To achieve such a goal, it is possible to optimize tractor engine performance or replace fossil fuel by an alternative fuel.
Ryan et al. [3] and Strayer et al. [4] stated that engine performance depends on the fuel used, the fuel injection, and the combustion characteristics. Engine manufacturers have improved diesel engines in terms of thermal efficiency (TE) by adopting several new technologies such as turbochargers, common rail system, multistage injection, and others. On the other hand, this engine performance increment in many cases caused a negative impact on emissions, and having in mind emission regulations, a solution could also be found in the application of alternative fuels of renewable nature, the so-called biofuels [5]. Biofuels have usually agricultural origin offering environmental benefits (i.e., exhaust emission reduction, nontoxicity) as well as decreasing countries' dependency on fossil fuels and improving agricultural income. The most common biofuels, which have already found their position in European fuel market, are bioethanol, vegetable oils, and their derived methyl esters (biodiesel). As agricultural tractors are powered by diesel engines, vegetable oils (VOs) that could be produced within the farm and used by agricultural tractors were only considered in this study. 
VOs and diesel fuel (DF) have similar physical and chemical properties. When VOs are used as fuels on short-term tests, no problems are indicated, while on endurance tests a number of problems have been reported with injection coking (causing poor fuel atomization and dilution of the lubricating oil), cylinder deposits, ring sticking as well as solidification in cold operating temperatures [5-7]. The main reason for these drawbacks of VOs is viscosity that is up to 16 times higher than conventional DF. This parameter is crucial, because it causes larger VO droplets, which in combination with the higher distillation curves of VOs creates a slower evaporation process that considerably affects engine's combustion rate [5]. Therefore, it is essential to either change the engine characteristics to adapt with the new fuel type or to reduce viscosity. For instance, Higelin [8] interfered in the engine internal parts substituting the typical aluminum alloy piston of an agricultural tractor direct injection diesel engine (IDE) by an insulated piston with a stainless steel crown, which corresponded well in the combustion characteristics of pure sunflower oil. Nevertheless, most research has been directed to changing the fuel characteristics, which gives the advantage of not modifying existing engines. Consequently, different methods have been stated, such as fuel blending, fuel heating, esterification of vegetable oils, and thermal cracking $[9,10]$.

\section{Literature Review}

Fuel blending and heating have the advantage of nonindustrial intervention, which is ideal for rural, remote areas where the farmers do not have easy access to the market. Many researchers have worked in these methods with different VO types, with positive results. However, for the purposes of this study, a specific investigation in previous work related to three VOs [sunflower oil (SunO), rapeseed oil (RapO), and cottonseed oil (CotO)] was carried out.

Nwafor and Rice [11] tested RapO blends up to neat RapO in an IDE and concluded that all blends were acceptable in comparison to DF and the $50 \%$ blend gave the best results. In particular, BSFC was in the same level for all fuels; except in high load levels where neat RapO gave higher BSFC. Thermal efficiency (TE) was found to be better as oil content in the tested fuel was increased. Exhaust gas temperature followed the same trend as thermal efficiency and engine lubrication oil performed well, showing acceptable viscosity reduction. Unburned hydrocarbons were lessened when neat RapO was used. McDonnell et al. [12] used semirefined RapO blends up to $75 \%$ in an agricultural tractor direct injection diesel engine (DDE) and resulted that oil blends up to $25 \%$ were suitable alternative fuels. More specifically, as oil content in the fuel was increased, Power was reduced and BSFC was augmented, but according to the tractor operators, engine performance was not affected highly; while engine lubricating oil was slightly influenced from the fuel alteration and injector fouling was increased, but not quantified. Karaosmanoğlu et al. [13] completed a 50-hour endurance test of a DDE with SunO, and there were no significant changes in engine operation in comparison to DF. More precisely, there was no significant drop or increase of power or fuel consumption. The lubrication oil was not affected remarkably and injector nozzle was clean. Altin et al. [14] compared several preheated VOs in a DDE with minor power loss and emission increase. Between the tested VOs, SunO, CotO, and RapO were tested and rapeseed had better engine performance and cottonseed better emissions. The worst torque release was obtained with SunO and the best with RapO. The least power output was released with CotO, while the highest values were taken when RapO was used. SunO gave the highest BSFC. CO emissions were most increased with $\mathrm{RapO}$, and $\mathrm{CO}_{2}$ was higher with $\mathrm{SunO}$, followed by RapO and CotO. $\mathrm{NO}_{2}$ was lower with CotO, followed by SunO and RapO. Smoke level was the highest with RapO, followed by CotO and SunO. Rao and Mohan [15] investigated the effect of supercharging on a DDE performance with $\mathrm{CotO}$ and found that changes in injection pressure did not affect performance, but supercharging, even if low, provided better performance with BSFC reduction. Nwafor [16] examined fuel inlet temperature effect on RapO and resulted that fuel heating was beneficial at low speed and part-load operation. Particularly, RapO was selected to be preheated at $70^{\circ} \mathrm{C}$ according to laboratory tests, and it was seen that peak cylinder pressure was increased accompanied by a reduced delay period in comparison to unheated RapO. In addition, heat release was early like with DF, in contrast to unheated RapO where it is late. BSFC was increased with preheated RapO, compared to unheated RapO. In high loads, this increment was eliminated due to the fact that combustion temperature dominated the delivery rates and flow velocities in the fuel line and resulted in the same system temperature for both preheated and unheated RapO. Preheated RapO deteriorated TE compared to unheated RapO, explained by the higher viscosity of neat oil that acts like a lubricant and as a sealant between the piston rings and the cylinder wall. Ramadhas et al. [10] conducted a literature review about VO use in Compression Ignition (CI) engines and concluded that in technical terms it is important to carry out experimental work with different engine types and sizes to increase confidence in these fuels. He and Bao [17] used cottonseed oil blends in an agricultural diesel engine and preliminary testing revealed that 30\% CotO had the best blend homogeneity (no sediment appearance). Therefore, they tried to optimize four parameters (intake valve closing angle, exhaust valve opening angle, fuel delivery angle, and injection pressure) to reach the highest TE. They came to the conclusion that fuel delivery angle was the most important factor and that $3-5^{\circ} \mathrm{CA}$ in advance would increase TE. Rakopoulos et al. [5] used 10 and 20\% blends of CotO, SunO, soybean, corn, and olive kernel oil with DF in a DDE and resulted that low oil content biofuels could be used safely and advantageously in diesel engines. They found out that TE was maintained close to DF, with small BSFC increase. Smoke and $\mathrm{CO}$ were augmented as the oil content in the fuel was increased. $\mathrm{NO}_{x}$ emissions were reduced as fuel oil percentage was increased. Wang et al. [18] used VO/DF blends in a DDE and concluded that power and BSFC was almost the same with DF and $\mathrm{NO}_{x}$, while $\mathrm{CO}$ and unburned hydrocarbons (HC) were lowered. Fontaras et al. [19] and Fontaras et al. [20] tested, respectively, $10 \%$ and 20\% CotO/DF blends in 
TABLe 1: Engine Specifications.

\begin{tabular}{lc}
\hline Make & Case New Holland \\
\hline Type & Four Stroke direct injection diesel engine \\
No. of cylinders & 4 \\
Aspiration & Turbocharged \\
Cooling System & Water cooled \\
Stroke $(\mathrm{mm})$ & 132 \\
Bore $(\mathrm{mm})$ & 104 \\
Engine Capacity $\left(\mathrm{cm}^{3}\right)$ & 4485 \\
Compression Ratio & 17.5 \\
Type of fuel pump & RDP \\
\hline
\end{tabular}

a Euro 3 common rail DDE of a passenger vehicle, and there was no significant influence in either engine performance or emissions. The $10 \%$ CotO blend was found to cover all EN590 standard specifications, and it was used successfully on the car for $12000 \mathrm{~km}$ millage. Fuel consumption and $\mathrm{CO}_{2}$ were fluctuating within the acceptable accuracy limits. $\mathrm{NO}_{x}$ were increased slightly in some cases, but never exceeded the Euro 3 emission limit.

In this study, a comparative study of SunO, RapO, and CotO was performed to observe a typical agricultural tractor engine behavior in terms of performance and emissions. The VOs were both preheated and blended with DF to minimize the high viscosity effect on engine operation. According to literature, a comparison of the selected VOs has not been executed on a total engine operation range and especially in an agricultural tractor engine. For Greek agriculture, it is also important to carry out testing of these VOs, which are major crops in the country and could be used for farm energy needs.

\section{Materials and Methods}

\subsection{Experimental Apparatus}

3.1.1. Engine Description. The engine selection was based on the average tractor engine power in Greek agriculture [21]. The engine used was a Case New Holland CNH 100A, four cylinder CI engine. It is a turbocharged, direct injection diesel engine with a rotational speed range of 700-2500 rpm. The injector nozzle sprays the fuel through 6 holes, forming a cone angle of $60^{\circ}$. The spraying starts when fuel line pressure reaches 250 bar. The rotary distribution principle (RDP) type "Bosch" fuel pump provides the fuel line with a pressure between 260 and 274 bar. The exhaust valve opens at $64^{\circ} \mathrm{CA}$ before top dead center (BTDC) and close at $26^{\circ} \mathrm{CA}$ after top dead center (ATDC), while the inlet valve opens at $10^{\circ} \mathrm{CA}$ BTDC and closes at $10^{\circ} \mathrm{CA}$ ATDC. The main specifications of the engine are illustrated in Table 1.

3.1.2. Test Rig Description. The experimental apparatus is shown in Figure 1. The engine was coupled on a Borghi and Saveri hydraulic dynamometer. The load on the dynamometer was measured by using a computer controlled strain gauge load sensor, which was calibrated using standard
TABLE 2: Accuracy of measurements.

\begin{tabular}{lccc}
\hline Measurement & Unit & Measurements range & Accuracy \\
\hline $\mathrm{CO}$ & \%vol. & $0-15$ & 0.01 \\
$\mathrm{CO}_{2}$ & \%vol. & $0-20$ & 0.01 \\
$\mathrm{NO}$ & ppm & $0-5000$ & 1 \\
$\mathrm{NO}_{2}$ & ppm & $0-1000$ & 1 \\
$\mathrm{HC}$ & ppm n-hexane & $0-20000$ & 1 \\
$\mathrm{O}_{2}$ & \%vol. & $0-25$ & 0.1 \\
\hline
\end{tabular}

weights before the experiments. A proximity speed sensor was used to measure the speed of the engine, which was also calibrated by an optical tachometer.

The fuel consumption was measured using a burette with $100 \mathrm{~mL}$ volumes and a stopwatch. A conical funnel instrument was introduced just before the fuel tank. When the fuel volume of the burette was vacated into the funnel, the time measuring was started and when the $100 \mathrm{~mL}$ were consumed the measuring was terminated. This way, a rate of fuel consumption in relation to time was taken. The measurement was carried out three times. The throttle position was controlled by a mechanical actuator and it was stabilized in full throttle. Temperatures in all cylinders, inlet and outlet coolant, air filter, exhaust gas, air inlet manifold (after turbo charger), fuel line, and engine oil were recorded every second using a series of k-type thermocouples. Pressures in air inlet manifold, exhaust manifold, and fuel line were also recorded, using Gems, UK 2200 series high output pressure transducers. Finally, air flow before the air filter was being recorded using an insertion calorimetric sensor (FCS-GL1/2A2P-LIXH1141/A, Turck, Germany). All temperature sensors were led to a temperature data logger (TC-08, Pico Technology, UK). All pressure and flow sensors were led to a general purpose voltage input data logger (ADC-24, Pico Technology, UK). Both data loggers were USB-connected to a PC, where data were stored. A new fuel tank was connected to the system for the alternative fuels.

3.1.3. Exhaust Gas Analysis System. The exhaust gas analysis was consisted by a rigid emission gas analyzer (DELTA 1600L by MRU, Germany) that measures $\mathrm{CO}, \mathrm{CO}_{2}, \mathrm{NO}_{x}, \mathrm{HC}$, and $\mathrm{O}_{2}$. The Nitrogen Oxides $\left(\mathrm{NO}\right.$ and $\mathrm{NO}_{2}$ ) were measured in parts per million (ppm), by volume with a chemiluminescent sensor. The $\mathrm{CO}$ and $\mathrm{CO}_{2}(\%)$ were determined by a NonDispersive Infrared Analyzer (NDIR) and the unburned HC in ppm, by volume with a Flame Ionization Detector Sensor (FID). The range and the accuracy of each measurement are given in Table 2.

3.1.4. External Fuel Preheating System. A VO preheating kit was installed for the preheating of the alternative fuels during the experimental work. A diagram of the kit is illustrated in Figure 2.

The manufacturer (W. Uhlig-U.T.G., Switzerland) provides this product for preheating pure VOs which are being used straight in the engine as fuels. In this work, it was used for preheating the selected VO/diesel blends, which was 


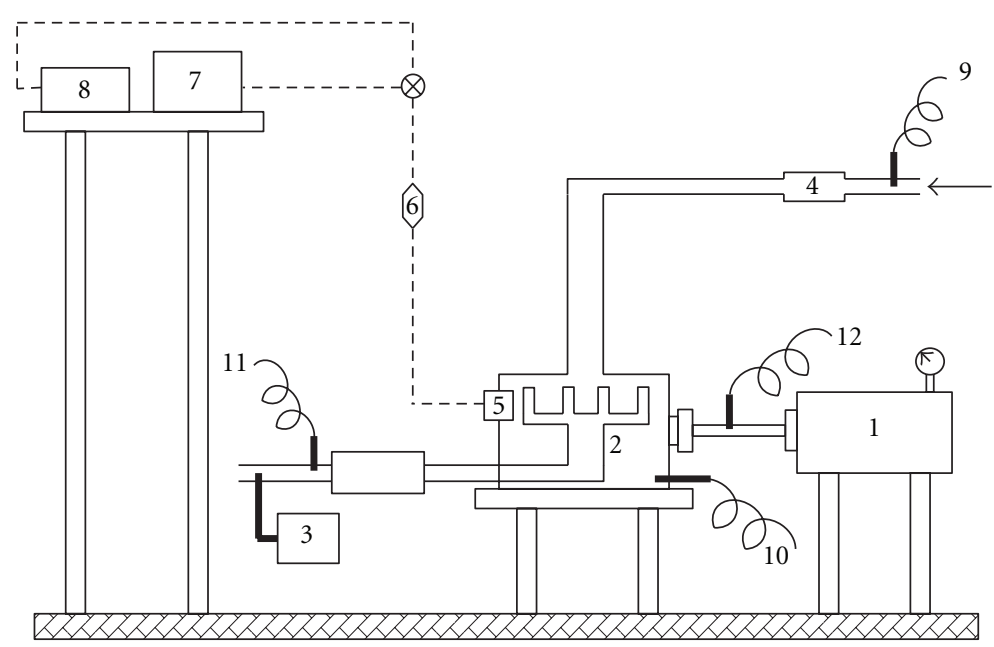

Figure 1: Experimental rig (1: Hydrokinetic Dynamometer, 2: Engine, 3: Gas Analyzer, 4: Air Filter, 5: Fuel Pump, 6: Burette, 7: Diesel Fuel Tank, 8: Alternative Fuel Tank, 9: Air Flow Meter, 10: Engine Oil Temperature, 11: Exhaust Gas Temperature, 12: Engine Speed Meter.

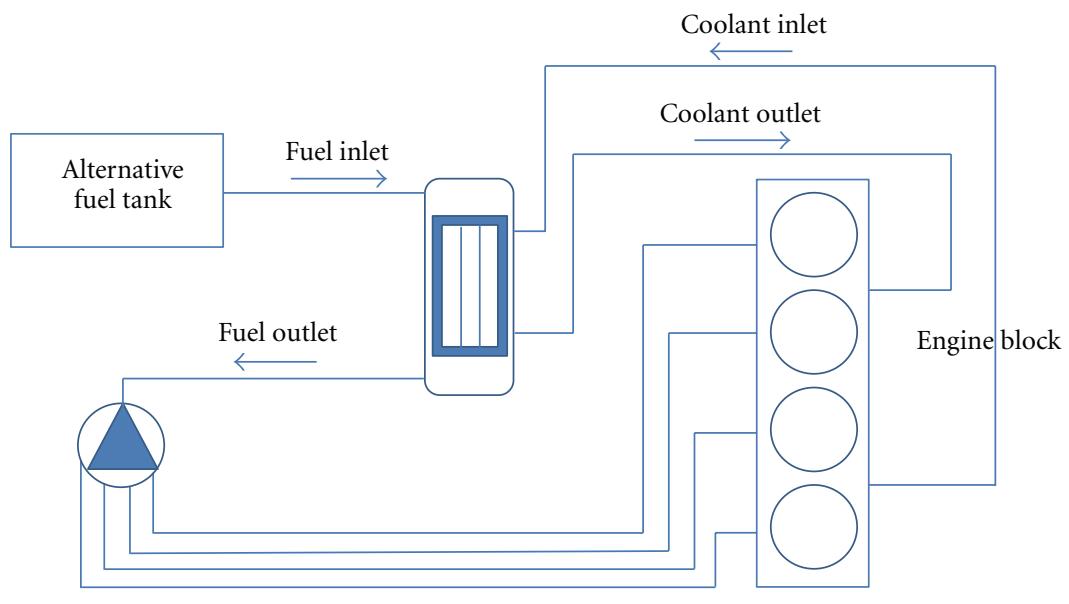

FIGURe 2: Preheating oil kit installed on the engine.

being carried out in a heat exchanger, through which engine coolant passes. At normal operation, the coolant temperature reached $85-92^{\circ} \mathrm{C}$. The alternative fuel, passing through the heat exchanger received heat and extended its temperature in a range of $65-75^{\circ} \mathrm{C}$, due to engine load change. Until the engine reached normal operating temperature, it run on conventional DF and the alternative fuel was not passing through the exchanger. When the coolant reached the abovementioned fixed temperature, then with a three-way valve the fuel switched from DF to the selected alternative fuel.

3.1.5. Viscosity Measurements. Viscosity was measured using Ubbelohde type (Comecta type 0B, 1, 1C, and 2) glass viscometers. VOs and the VO/DF blends were prepared and oven preheated in temperatures ranged between ambient temperature $\left(22^{\circ} \mathrm{C}\right)$ and $98^{\circ} \mathrm{C}$. Eight measurements for each of the 13 alternative fuels were carried out with $10^{\circ} \mathrm{C}$ interval.

3.2. Experimental Procedure. The VOs used were all Greek originated, as the oil seeds were produced in three farms in Sterea Ellada Province, Greece, and were extracted onsite with the same procedure (screw expeller and filtration). Originally, the engine was run using DF and the results were used as reference point. Then, four (4) types of fuels for each VO were experimented; three VO/DF blends (20/80, 40/60, and $70 / 30$ volumetrically) and $100 \%$ pure VO. The selection of blends was based on previous studies [11, 12, 17, 22, 23] and aimed on an overall blend range. DF was used in ambient temperature and only blends and pure VOs were first preheated. The blends were stirred well and the mixture remained always in a stable condition, which was shown by the fact that the blends remained stable after a 20-day idle in transparent tanks.

Initially, the engine was warmed until it reached operating temperature. The engine speed was then increased to maximum, which is $2300 \mathrm{rpm}$. The tests were performed according to OECD procedure [24] for tractor engines. Initially the maximum power is defined, which is usually detected by small changes around the given manufacturer maximum power engine speed. Then, five part load tests follow. 
TABLe 3: Physical and chemical properties of the three vegetable oils and diesel fuel.

\begin{tabular}{|c|c|c|c|c|c|}
\hline $\begin{array}{l}\text { Fuel Type } \\
\text { Acronym }\end{array}$ & & $\begin{array}{c}\text { Diesel } \\
\text { DF }\end{array}$ & $\begin{array}{c}\text { Sunflower oil } \\
\text { SunO }\end{array}$ & $\begin{array}{c}\text { Rapeseed oil } \\
\text { RapO }\end{array}$ & $\begin{array}{c}\text { Cottonseed oil } \\
\text { CotO }\end{array}$ \\
\hline Calorific value & $\mathrm{MJ} / \mathrm{kg}$ & $43.350[10]$ & $39.525[10]$ & $37.620[10]$ & $39.648[10]$ \\
\hline Viscosity at $35^{\circ} \mathrm{C}$ & $\mathrm{cSt}$ & 3.05 (measured) & 40.96 (measured) & 42.38 (measured) & 41.67 (measured) \\
\hline Density at $25^{\circ} \mathrm{C}$ & $\mathrm{kg} / \mathrm{m}^{3}$ & $815[10]$ & $918[10]$ & $914[10]$ & $912[10]$ \\
\hline Carbon residue & $\%$ & Max 0.4 [25] & $0.13[26]$ & $0.3[25]$ & $0.23-0.25[27]$ \\
\hline Ash content & $\%$ & $\operatorname{Max} 0.01$ [25] & $<0.01[26]$ & $0.003[25]$ & $0.02[28]$ \\
\hline Cetane number & - & $47[10]$ & $37.1[10]$ & $37.6[10]$ & $48.1[10]$ \\
\hline Iodine value & cg I.g oil & $95-125$ [25] & $126.3[29]$ & $112[25]$ & $103-115[30]$ \\
\hline Saponification value & $\mathrm{mgKOH} / \mathrm{g}$ oil & - [29] & $191[29]$ & $197.07[28]$ & $207.71[28]$ \\
\hline Sulphur content & $\%$ & $0.27[12]$ & $0.01[28]$ & $0.00[12]$ & $0.008-0.010[27]$ \\
\hline Water content & $\%$ & $<0.1[31]$ & $<0.1[31]$ & $0.06[25]$ & - \\
\hline Carbon content & $\%$ & $87.5[31]$ & $77.6[31]$ & - & - \\
\hline Flame point & ${ }^{\circ} \mathrm{C}$ & $58[14]$ & $220[14]$ & $275-290[14]$ & $210[14]$ \\
\hline Flash point & ${ }^{\circ} \mathrm{C}$ & $76[32]$ & $274[32]$ & $246[32]$ & $234[32]$ \\
\hline Cloud point & ${ }^{\circ} \mathrm{C}$ & $-2.2[13]$ & $7.2[32]$ & $-3.9[32]$ & $1.7[32]$ \\
\hline Pour point & ${ }^{\circ} \mathrm{C}$ & $-12.2[13]$ & $-15[32]$ & $-31.7[32]$ & $-15[32]$ \\
\hline CFPP & ${ }^{\circ} \mathrm{C}$ & $-10.1[13]$ & $-18[13]$ & $-15[13]$ & $-6[33]$ \\
\hline Chemical formula & - & $\mathrm{C}_{16} \mathrm{H}_{34}[14]$ & $\mathrm{C}_{57} \mathrm{H}_{103} \mathrm{O}_{6}[14]$ & $\mathrm{C}_{57} \mathrm{H}_{105} \mathrm{O}_{6}[14]$ & $\mathrm{C}_{55} \mathrm{H}_{102} \mathrm{O}_{6}$ [14] \\
\hline
\end{tabular}

The first test is taken at the torque corresponding to maximum power, the second with $85 \%$ of the torque defined in the first test, the third with $75 \%$ of the second test torque, the fourth with $50 \%$ of the second test torque, and the fifth with $25 \%$ of the second test torque. In this study, the procedure of the code was followed, with an exception of the last mentioned test that was not carried out, because the dynamometer had a very large torque range and it could not reach such a low point. In order to cover the whole engine load range, two more part load tests were added that resulted in eight comparable points of the engine operation range. In every load test, power, torque, fuel consumption, engine temperatures and pressures, air flow, and gas emissions were measured. Atmospheric pressure and air temperature were also recorded, and measured torque was corrected according to them. At each point, the engine was stabilized for three minutes and then the measurements were taken. Three measurements of all parameters, per minute, were recorded for every test, for eliminating statistical errors. The warmingup of the engine in all the experiments was conducted using DF. After warming-up, the alternative fuel was used and in the end of the experimental procedure the fuel was again switched to DF, in order to flush out the fuel lines, the injection pump and the injectors before shutting down.

Finally, the results from the tests were statistically analyzed. They were compared using pair $t$-tests with $95 \%$ confidence interval. The statistical analysis was carried out with the SPSS Release 16 (SPSS Inc., 2007).

\section{Results and Discussion}

4.1. Fuel Properties. The main properties of the three tested VOs and DF are shown in Table 3. VOs exhibit high values of viscosity that could be reduced by preheating or blending with DF as stated above. In this study, viscosity testing was
TABLE 4: Engine performance parameters with diesel fuel (reference fuel).

\begin{tabular}{lccc}
\hline Parameter & $\begin{array}{c}\text { Engine speed } \\
(\mathrm{rpm})\end{array}$ & Load (\%) & Value \\
\hline Max Power (kW) & 2198 & 69.75 & 64.1 \\
Max Torque (Nm) & 1280 & 100 & 399.2 \\
Max Thermal Efficiency (\%) & 1574 & 90.1 & 36.45 \\
Min BSFC (g/kWh) & 1574 & 90.1 & 228.5 \\
\hline
\end{tabular}

conducted for all 13 tested fuels to comprehend the effect of high temperature and mixing with DF on the final fuel viscosity. The results are illustrated in Figure 3.

The temperature range under consideration was 65$75^{\circ} \mathrm{C}$, which was the fuel inlet temperature after passing from the preheating device. Hence, in comparison to DF in ambient temperature $\left(23^{\circ} \mathrm{C}\right)$, the preheated $\left(65-75^{\circ} \mathrm{C}\right) 20 / 80$ blends showed lower viscosity values (30-40\%) and the 40/60 blends had viscosity values ranging between -5 and $+10 \%$. The 70/30 blends had 60-120\% higher viscosity and the pure VOs 200-340\% higher values than DF. From Figure 3, it is obvious that the three VOs followed the same trend as the blend oil content and temperature increase.

4.2. Engine Performance. In order to evaluate the alternative fuels in terms of engine performance, a comparison of the 13 fuels under investigation was conducted, in terms of power and torque output, BSFC and total TE. The measured values for these parameters using DF as the reference point are illustrated in Table 4.

In the comparison of the engine performance parameters, which is illustrated in the following Figures 4-8, every parameter is shown as a difference percentage from the respective DF reference value. 
Sunflower oil

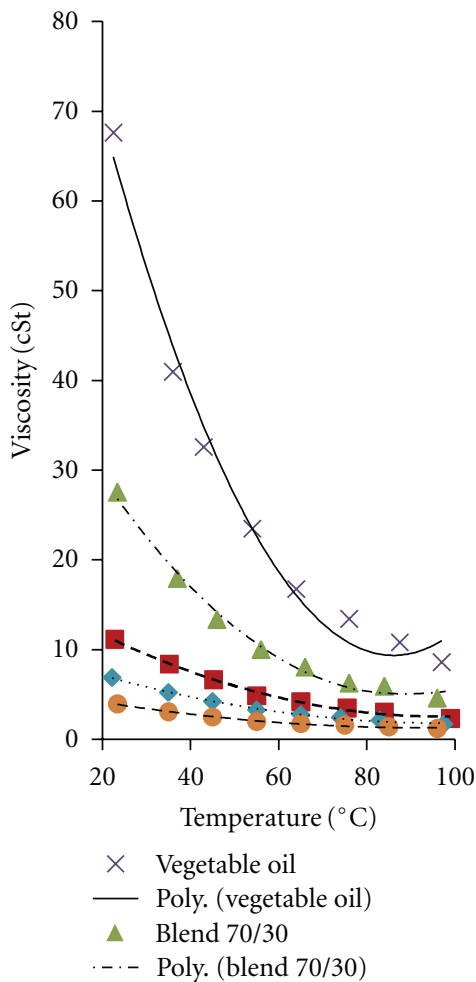

Rapeseed oil

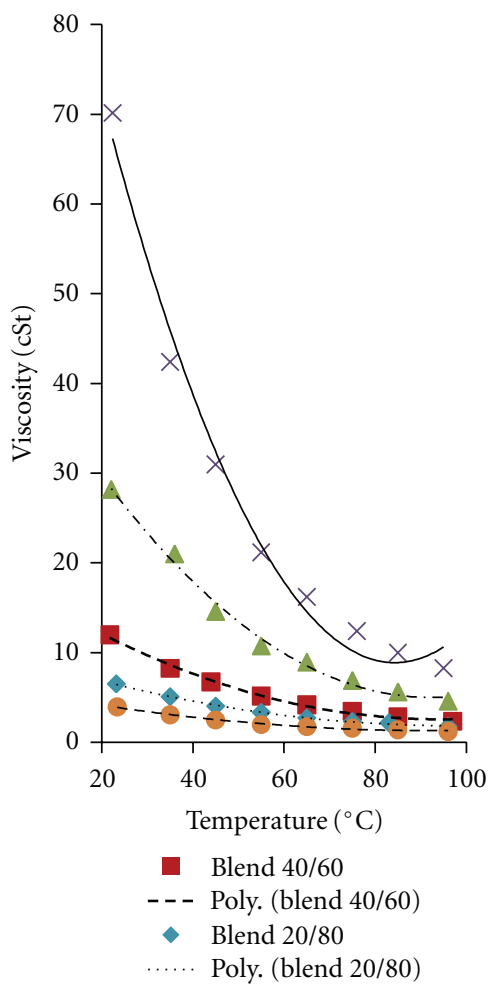

Cottonseed oil

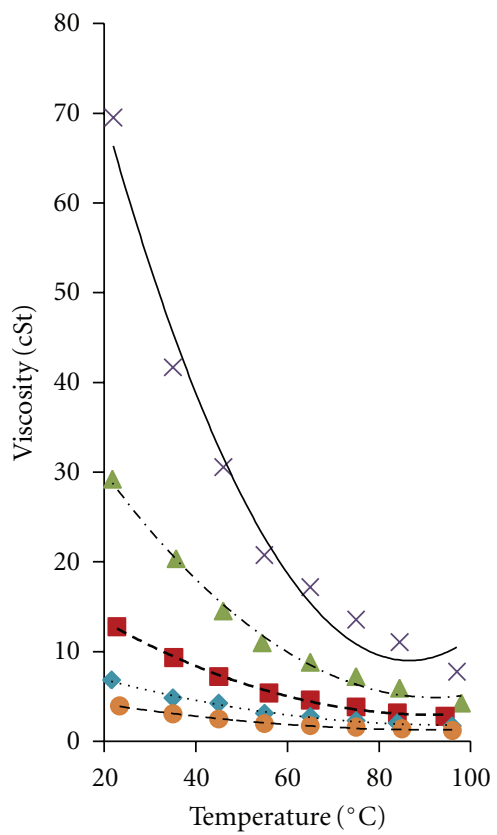

- Diesel fuel

- - Poly. (diesel fuel)

Figure 3: Viscosity measurements for diesel and the three oil types.

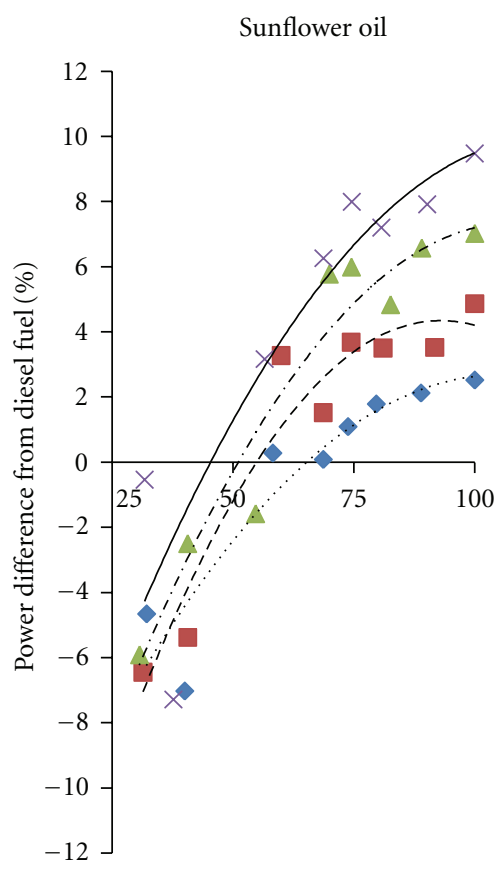

Load $(\%)$

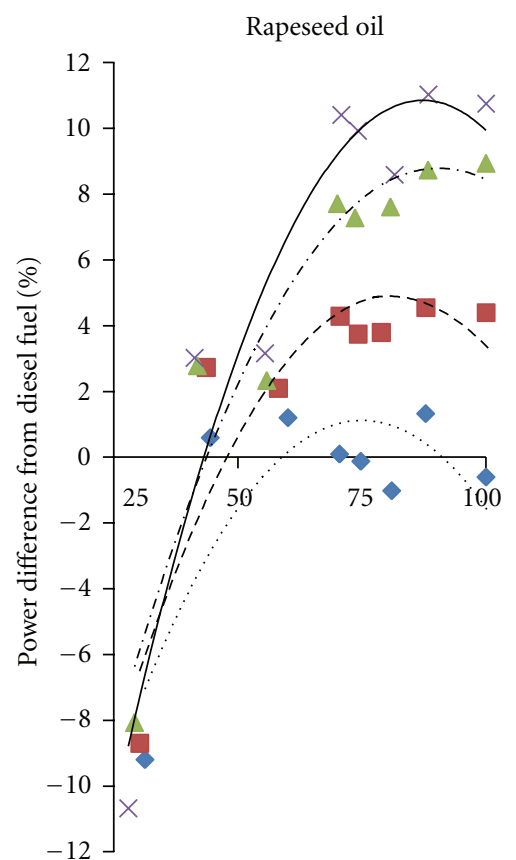

Load $(\%)$

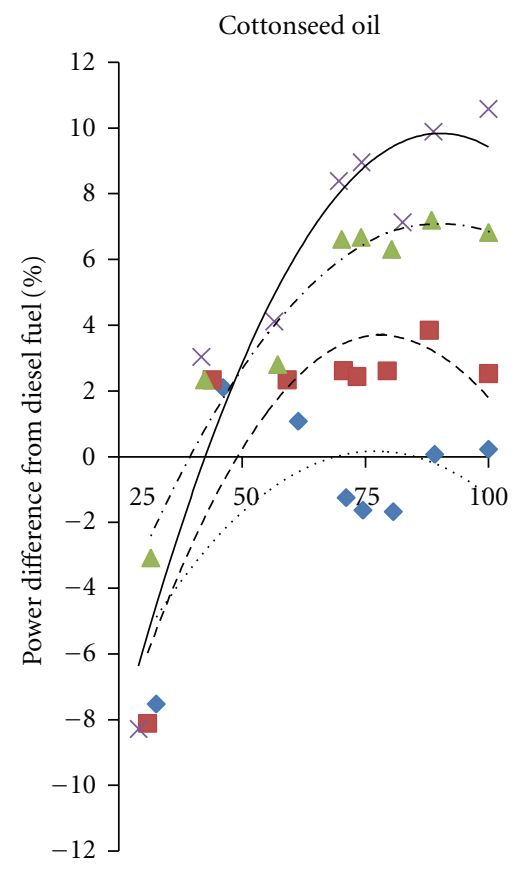

Load (\%)

Blend 20/80 Poly. (blend 20/80)

- Blend $40 / 60$

- - Poly. (blend 40/60)

$\triangle \quad$ Blend $70 / 30$

-. Poly. (blend 70/30)

$\times \quad$ Vegetable oil

— Poly. (vegetable oil)

Figure 4: Comparison of Power output between diesel fuel and the three oil types. 


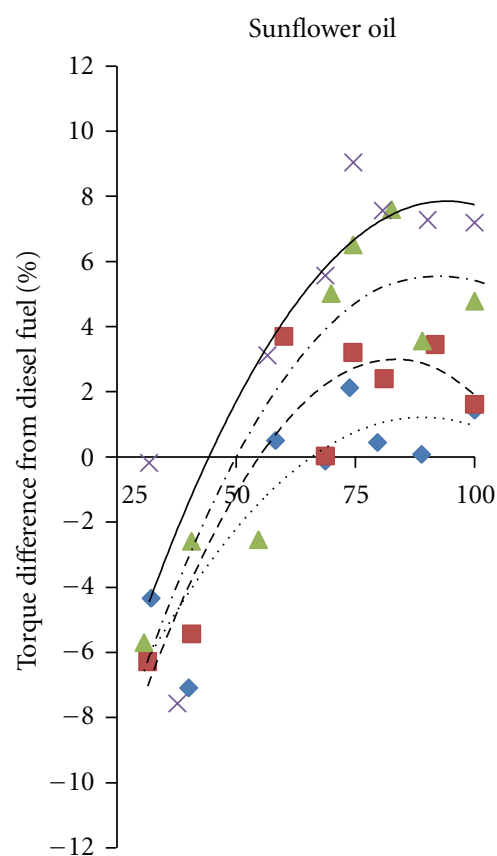

Load (\%)

- Blend 20/80

Poly. (blend 20/80)

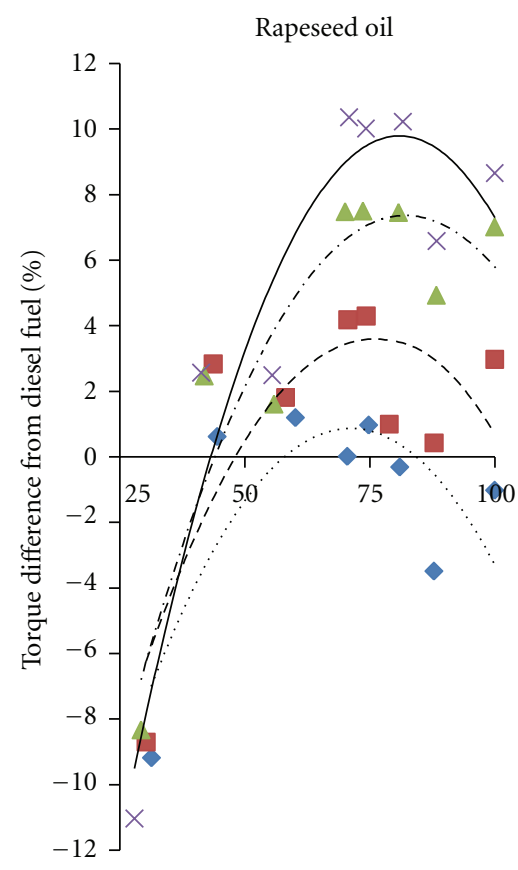

Load (\%)

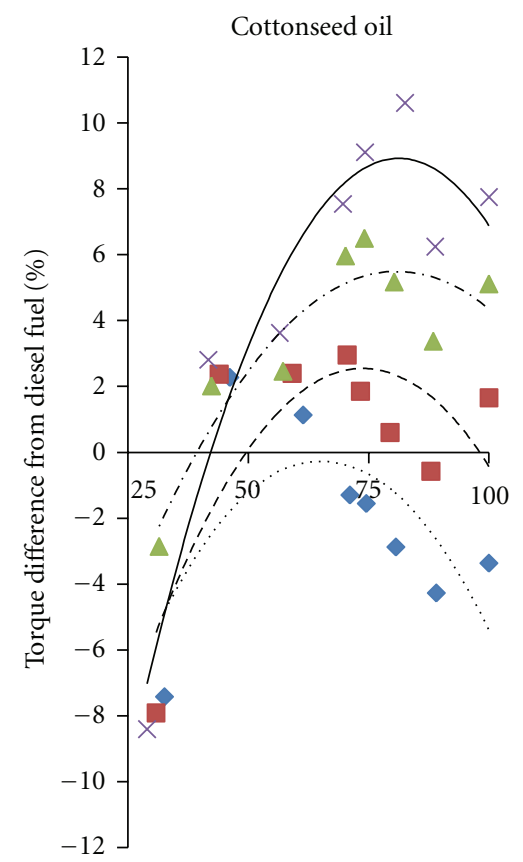

Load (\%)

$\Delta \quad$ Blend 70/30

-.- Poly. (blend 70/30) $\begin{array}{ll}\times \quad \text { Vegetable oil } \\ & \text { Poly. (vegetable oil) }\end{array}$

Figure 5: Comparison of Torque output between diesel fuel and the three oil types.

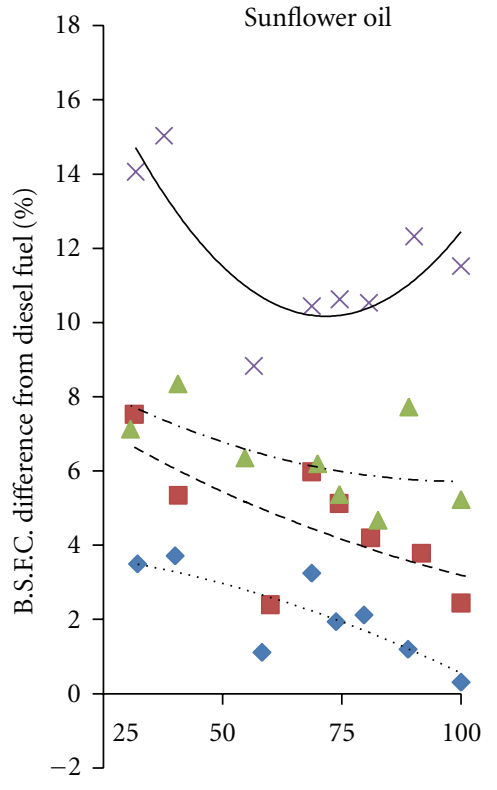

Load (\%)

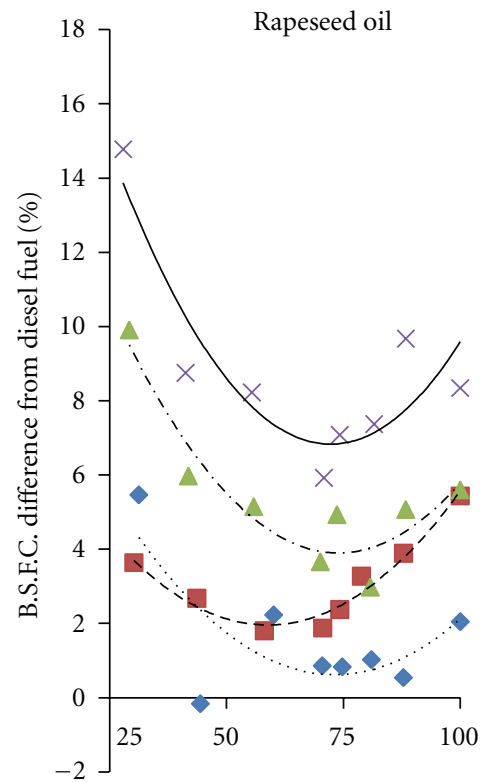

Load (\%)

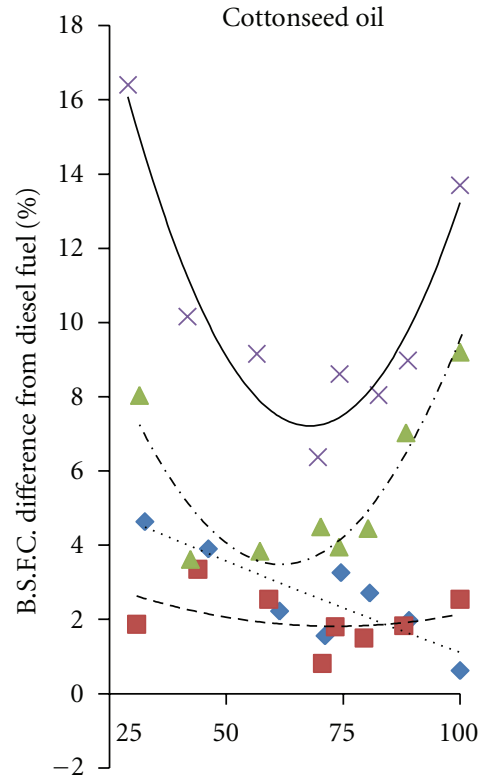

Load (\%)

$\times \quad$ Vegetable oil

- Poly. (vegetable oil)

- Blend 20/80

Figure 6: Comparison of B.S.F.C. between diesel fuel and the three oil types. 
Sunflower oil

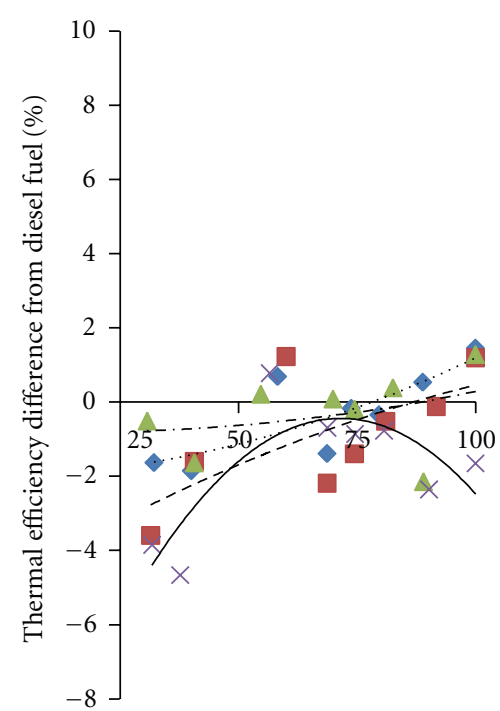

$\operatorname{Load}(\%)$
Rapeseed oil

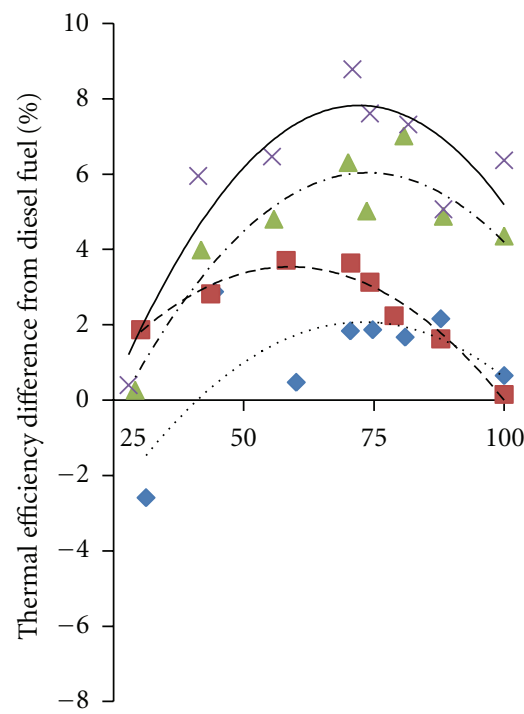

Load (\%)
Cottonseed oil

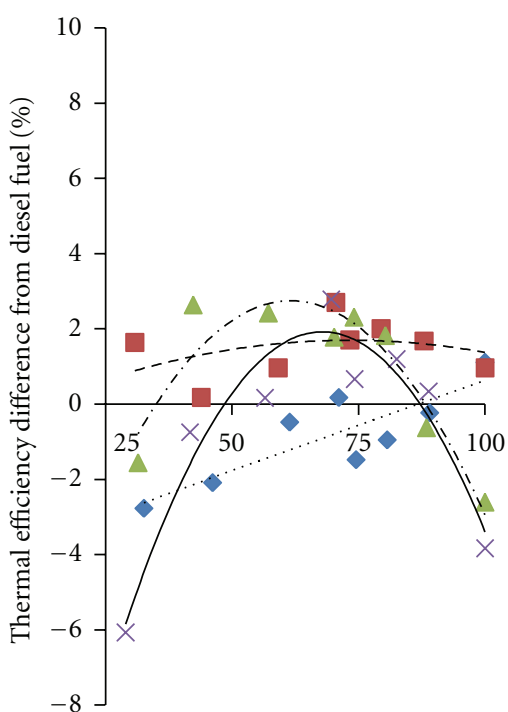

Load (\%)

$\times \quad$ Vegetable oil

A Blend 70/30

-. Poly. (blend 70/30)

Figure 7: Comparison of thermal efficiency between diesel fuel and the three oil types.

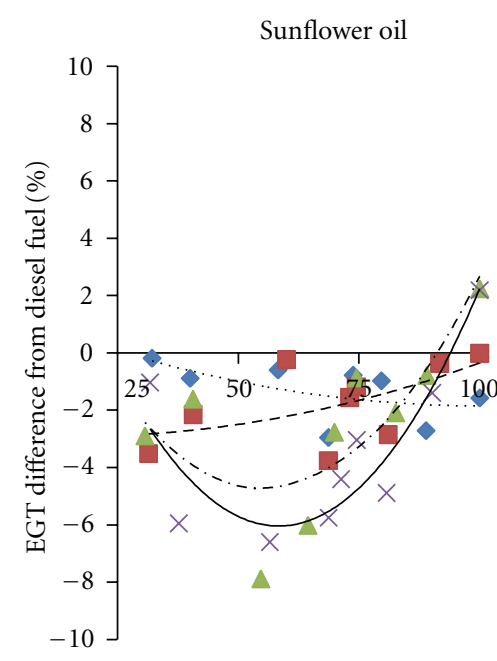

Load (\%)

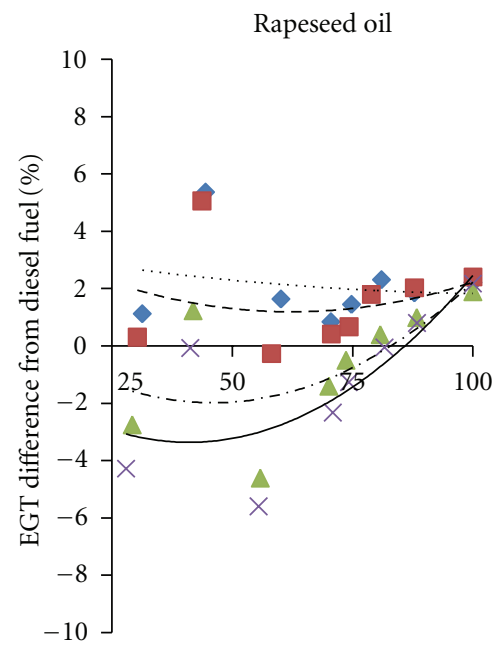

Load (\%)

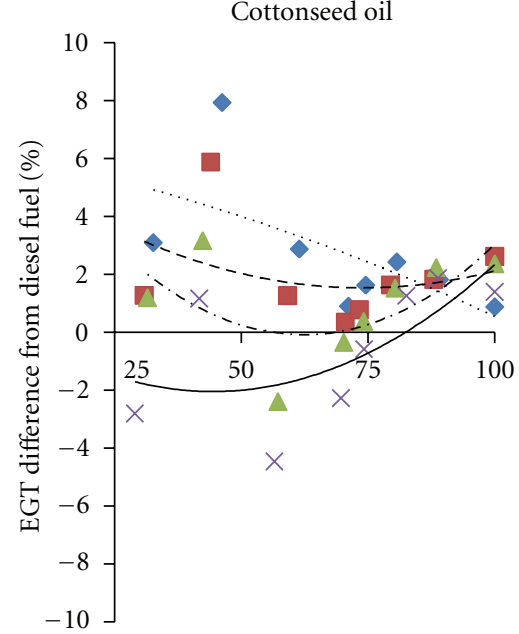

Load (\%)

$\times \quad$ Vegetable oil

_ Poly. (vegetable oil)

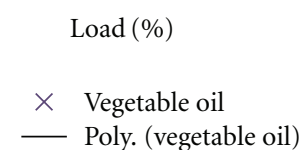

- Blend 20/80 Poly. (blend 20/80)
Blend 40/60

Poly. (blend 40/60)
Alend $70 / 30$
-. Poly. (blend 70/30)

FIGURE 8: Comparison of exhaust gas temperature between diesel fuel and the three oil types.

4.2.1. Power and Torque. The variations in power and torque of the engine with the VOs are presented in Figures 4 and 5, respectively. In high loads, all VOs followed the same trend of increased power and torque outcome as the oil content was increased.

However, in low loads, engine power and torque release were higher using DF. This phenomenon could be explained by the fact that in high load setting, the engine speed was low and the VO had more time to complete its combustion, as it always has a higher ignition delay and combustion rate [5]. In addition, it is possible that the combustion process was perhaps changed from evaporation controlled to mixing controlled as the load increased [34].

Comparing the three VOs, it was observed that RapO presented the highest power and torque difference than DF $(11 \%)$, in comparison to CotO (10.6\%) and SunO (9.5\%). 
The 70/30 blends followed the same trend as the pure VOs. Nevertheless, with lower oil content the engine seemed to behave better with SunO. It was seen that SunO40 gave the same increase as RapO40 and CotO40 was listed third. The SunO20 was the only $20 / 80$ blend to show natural continuation to the previous blends, when the other two gave scattered results with lower power and torque output in general. This was not expected, as the blending was made following the same procedure. Finally, it should be mentioned that only SunO based fuels showed a continuous increment until the maximum load.

4.2.2. Brake Specific Fuel Consumption. Figure 6 illustrates that all blends and pure VOs showed increased BSFC in comparison to DF. It is also demonstrated that as oil content was increasing, BSFC was also increased. This trend could be explained by the higher density of all VOs, which leads to increased gravimetric fuel consumption due to increased fuel mass for the same volume of fuel injected by the fuel pump. In addition, lower calorific value might also increase the volumetric fuel consumption to keep similar energy input to the engine $[23,35]$. In addition, as the engine load increases, BSFC decreases $[19,35]$. In this study, this trend was observed for all fuels. Between the three VOs, statistical significant differences were observed for the 40/60 blends and pure VOs. In the case of agricultural tractors, the engine runs in the range of $60-80 \%$ load, where most of agricultural practices are taking place. Therefore, it is positive that Figure 6 shows the least BSFC increase in appraisal to DF obtained within this specific range.

4.2.3. Thermal Efficiency. Figure 7 illustrates the Thermal Efficiency (TE) difference of the VOs from DF. Each of the VOs showed completely different output. RapO fuels have exhibited the best TE result, as power increase was considerably higher than the respective BSFC raise. In particular, the oil content of the fuel played a positive role in the final TE, with pure RapO indicating maximum increase of $8.4 \%$. from Apart RapO20, all RO fuels were statistically significantly different than DF (average TE increment: RapO 5.9\%, RapO70 $4 \%$, RapO40 2.5\%). The situation was altered significantly with SunO and CotO fuels, which generally presented lower TE, and there were no indication of oil content influence in TE. In general, CotO and SunO fuels did not show statistical differences from DF, except CotO40 (TE average increment of $1.1 \%$ ). Comparing the three VOs, RapO fuels were better than the other two VOs with statistical differences. According to these results, RapO seems to provide better combustion process, even if oil properties and viscosity in particular are in the same level as the other VOs. This could be explained as combustion is always enhanced by high air/fuel (A/F) mixture, good atomization, and spray characteristics [23]. Unsaturated oils enhance mixing, due to their loose bonds between the molecules [36]. Table 5 [37] displays the free fatty acid contents of the three tested VOs, and it can be seen that RapO contains the highest percentage of unsaturated fatty acids.
TABLE 5: FFAs content of the three tested oils [36].

\begin{tabular}{lccc}
\hline & $\begin{array}{c}\text { Saturated } \\
(\%)\end{array}$ & $\begin{array}{c}\text { Monounsaturated } \\
(\%)\end{array}$ & $\begin{array}{c}\text { Polyunsaturated } \\
(\%)\end{array}$ \\
\hline Sunflower oil & 11.9 & 20.2 & 63.0 \\
Rapeseed oil & 5.3 & 64.3 & 24.8 \\
Cottonseed oil & 25.5 & 21.3 & 48.1 \\
\hline
\end{tabular}

In addition, RapO has a lot of monounsaturated fatty acids, which gave an indication that these acids promote more air/fuel mixing.

4.2.4. Exhaust Gas Temperature. Engine exhaust gas temperature using as fuel the three VOs in comparison to DF is presented in Figure 8.

It is evident that this factor was not significantly changed in comparison to DF. The exhaust gas temperature (EGT) of CotO fuels is higher than the respective SunO and RapO fuels, as it is evident that highly polyunsaturated fatty acid oils exhibit higher ignition delay and shorter premixed combustion periods, which means that the after burning period is extended and the final temperature of the exhaust gases is higher $[36,38]$.

4.3. Engine Emissions. Investigation of performance characteristics has to be combined with engine emissions examination, in order to have an overall view of VOs as fuel in comparison to DF. The gas analyzer available had the capability of measuring unburned $\mathrm{HC}, \mathrm{CO}, \mathrm{O}_{2}, \mathrm{CO}_{2}$, and $\mathrm{NO}_{x}\left(\mathrm{NO}, \mathrm{NO}_{2}\right)$ and all of them were logged during the experiments.

However, $\mathrm{HC}$ and $\mathrm{CO}$ values were very low and according to the instrument accuracy (Table 2), they cannot be considered as reliable. More precisely, unburned HC were always between 0 and 5 pmm, while CO was measured in \%, which was not accurate enough to show the low $\mathrm{CO}$ values obtained from the measurements (the figures were always between 0.01 and $0.03 \%)$. Hence, $\mathrm{HC}$ and $\mathrm{CO}$ were not taken into account in the analysis below. In both cases, it should be stated that in absolute terms these emissions are of no real concern [5].

4.3.1. Nitrogen Oxides $\left(N O_{x}\right)$. Figure 9 presents the difference of $\mathrm{NO}_{x}$ emissions between the 12 alternative fuels and conventional DF. It can be observed that the use of VO had a significant influence in the $\mathrm{NO}_{x}$ emission level. It has to be pointed out that the main factor to receive increased $\mathrm{NO}_{x}$ emissions is the elevated cylinder temperature $[32,35]$.

In addition, according to Rakopoulos et al. [5], fuels with high cetane number (DF in this case) were expected to produce lower $\mathrm{NO}_{x}$ levels, due to lower ignition delay that creates shorter premixed combustion, which is the main phase of $\mathrm{NO}_{x}$ production. Moreover, the fact that the engine under testing exhibits a very high $\mathrm{A} / \mathrm{F}$ ratio added to $\mathrm{NO}_{x}$ increment, due to the $\mathrm{O}_{2}$ excess available for chemical reaction with the atmospheric $\mathrm{N}$. In addition, $\mathrm{O}_{2}$ is contained in the $\mathrm{VO}$ molecule and this resulted in higher $\mathrm{NO}_{x}$ emissions. As the oil percentage was increased, $\mathrm{NO}_{x}$ emissions were 


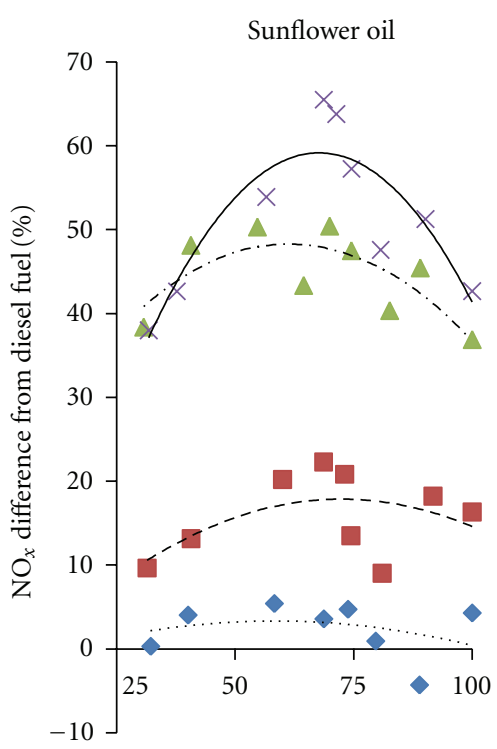

$\operatorname{Load}(\%)$

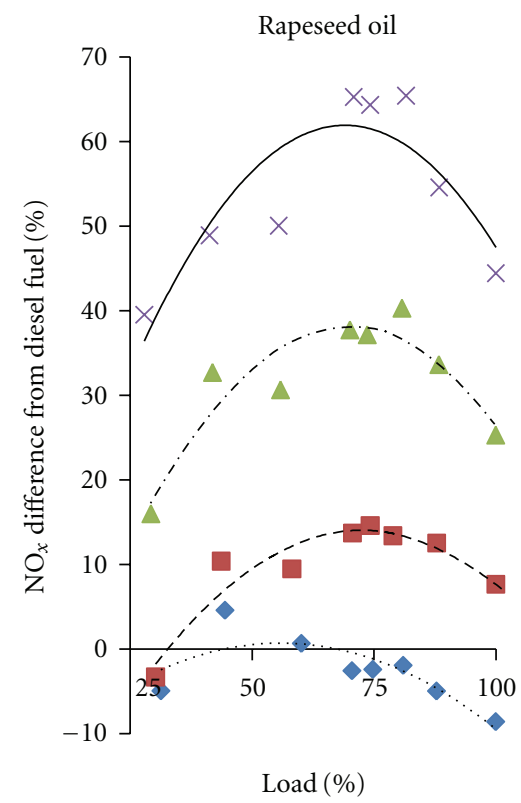

A Blend $70 / 30$

-. - Poly. (blend 70/30)
Cottonseed oil

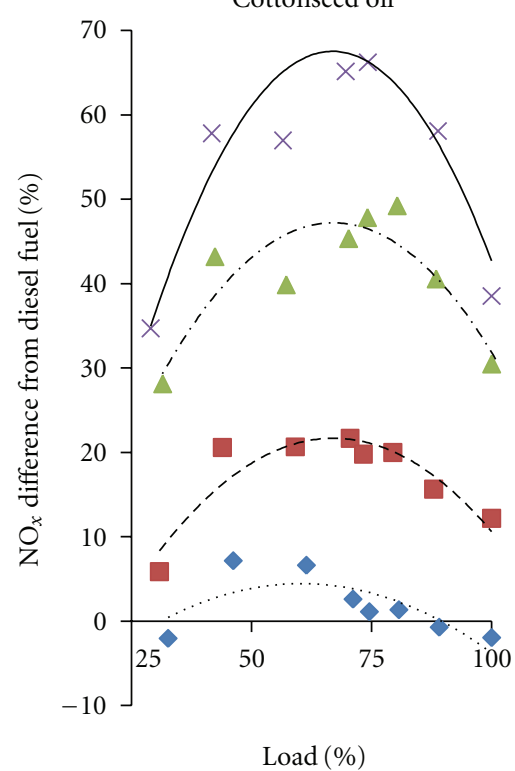

$\times \quad$ Vegetable oil

— Poly. (vegetable oil)

FIgURE 9: Comparison of $\mathrm{NO}_{x}$ between diesel fuel and the three oil types.

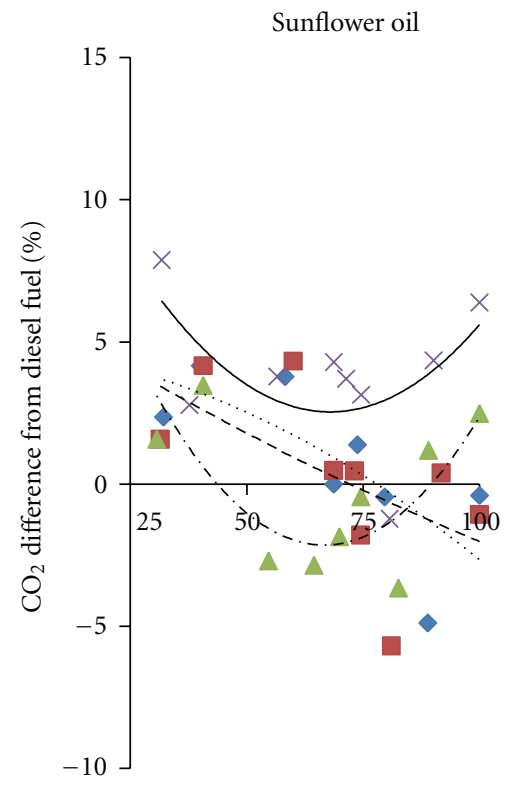

Load (\%)

- Blend 20/80

.... Poly. (blend 20/80)

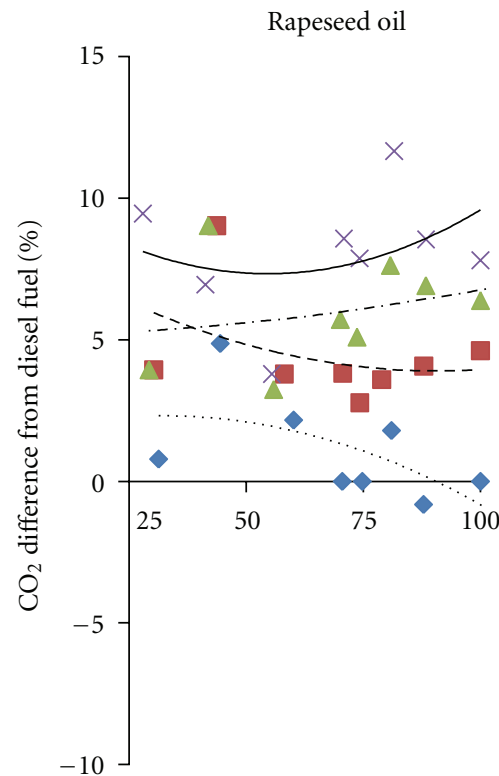

Load (\%)

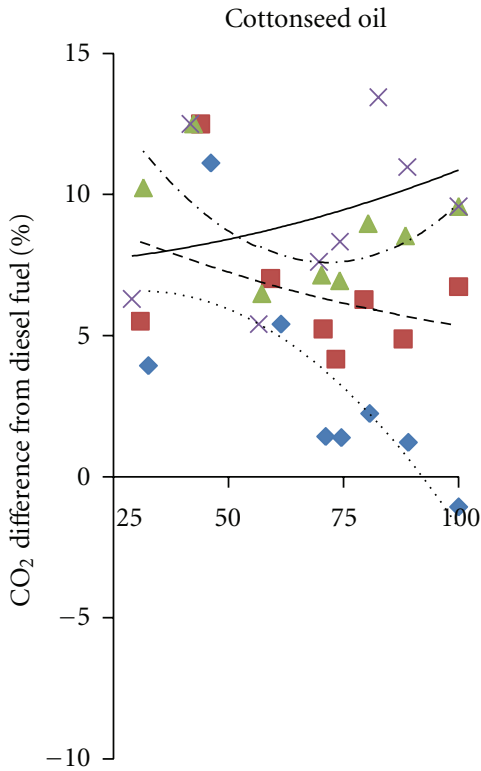

$\operatorname{Load}(\%)$

$\times \quad$ Vegetable oil

- Poly. (vegetable oil)

FIgure 10: Comparison of $\mathrm{CO}_{2}$ emission between diesel fuel and the three oil types.

augmented and the effect was similar for the three VOs. However, there was a noticeable phenomenon in the case of 20/80 blends; where all VOs gave positive and negative results with no statistical differences. It seems that in these blends the combination of DF and VO reduced the combustion temperature and reduced $\mathrm{NO}_{x}$ levels. This might happen due to bad fuel mixture with the air that led to incomplete combustion of lower temperature [5].

A general observation of Figure 9 illustrates that RapO fuels had the best behavior in terms of $\mathrm{NO}_{x}$ emissions. More specifically, RapO20, RapO40, and RapO70 produced statistically the least $\mathrm{NO}_{x}$ emissions, leaving the respective CotO 
fuels second and SunO fuels last. In the case of pure VOs, there were no statistically significant differences.

4.3.2. Carbon Dioxide $\left(\mathrm{CO}_{2}\right)$. Figure 10 presents the $\mathrm{CO}_{2}$ emissions produced by the $\mathrm{VO}$ fuels in comparison to DF. In general, with exception in RapO20 and CotO20, $\mathrm{CO}_{2}$ emissions were increased compared to DF. This is an indication of better combustion, due to oxygen content of VOs. It can be seen that high oil content increases $\mathrm{CO}_{2}$ levels. A tendency of lower $\mathrm{CO}_{2}$ values of SunO fuels is illustrated, leaving RapO fuels in the second place and CotO fuels last. This fact could be explained by better combustion characteristics of CotO, giving a less incomplete combustion.

\section{Conclusions}

An experimental investigation was conducted to evaluate the performance and exhaust emissions of three Vegetable oils [Sunflower Oil (SunO), Rapeseed Oil (RapO), and Cottonseed Oil (CotO)] and their blends with Diesel Fuel (DF) and compare the results with the reference fuel (DF). The work was conducted in a fully instrumented direct injection agricultural tractor engine. The conclusions extracted in terms of engine performance and exhaust emissions were as follows.

(i) All vegetable oil fuels provided as fuels to the engine had resulted in normal operation without problems during the short-term experiments.

(ii) The 20/80 blends showed unstable results with unclear trends, in comparison to higher oil content fuels.

(iii) Power, Torque, and BSFC were higher as oil content was increased in the tested fuel.

(iv) RapO-based fuels gave the best results in terms of Power and Torque increment with a simultaneous lower BSFC increase. As a result, engine thermal efficiency was significantly better than when using the other vegetable oils. CotO fuels were on average better than SunO fuels.

(v) $\mathrm{NO}_{x}$ emissions were augmented as oil percentage in the fuel was increased.

(vi) RapO fuels increased the $\mathrm{NO}_{x}$ production less than CotO fuels, leaving SunO fuels last.

(vii) $\mathrm{CO}_{2}$ emissions showed an increase tendency as the oil content was evolved when RapO and CotO fuels were used. SunO fuels gave blurred results on this issue.

(viii) The highest $\mathrm{CO}_{2}$ emissions were produced when CotO fuels were tested, followed by RapO and SunO fuels.

As a main conclusion, the use of RapO illustrated better behavior as alternative fuel to DF in the direct injection agricultural tractor engine of this study.

\section{Nomenclature}

ATDC: After top dead centre

BTDC: Before top dead centre
BSFC: Brake specific fuel consumption

CA: Crank angle

CI: Compression ignition

$\mathrm{CO}_{2}$ : Carbon dioxide

CO: Carbon monoxide

CotO: Cottonseed oil

DDE: Direct injection diesel engine

DF: Diesel fuel

HC: Hydrocarbons

IDE: Indirect injection diesel engine

$\mathrm{NO}_{x}$ : Nitrogen oxides

RapO: Rapeseed oil

RDP: Rotary distribution principle

SunO: Sunflower oil

TE: Thermal efficiency

VO: Vegetable oil.

\section{References}

[1] http://www.eea.europa.eu/data-and-maps/figures/final-en-ergy-consumption-by-sector-4, In: Agency EE, editor. 2011.

[2] P. Panagakis, G. Papadakis, T. Natsis, and S. Kyritsis, "Strategic $\mathrm{R} \& \mathrm{D}$ for better energy efficiency in the agricultural sector," In: CSMC) EPCNJ-C_-GD, editor. 1996.

[3] T. W. Ryan, T. J. Callahan, and L. G. Dodge, "Characterization of vegetable oil for use as fuels in diesel engines," in Proceedings of the International Conference on Plaint Oils as Fuels, pp. 7081, American Society of Agricultural Engineers, 1982, ASAE no. 49085 .

[4] R. C. Strayer, W. K. Craiq, and G. C. Zoerb, "Engine deposit and pour point studies using canola oil as a diesel fuel," in Proceedings of the International Conference on Plant and Vegetable Oils as Fuels, pp. 347-353, American Society of Agricultural Engineers, 1982, ASAE no. 49085.

[5] C. D. Rakopoulos, K. A. Antonopoulos, D. C. Rakopoulos, D. T. Hountalas, and E. G. Giakoumis, "Comparative performance and emissions study of a direct injection diesel engine using blends of diesel fuel with vegetable oils or bio-diesels of various origins," Energy Conversion and Management, vol. 47, no. 18-19, pp. 3272-3287, 2006.

[6] M. Zejewski, H. Goettler, and G. L. Pratt, "Influence of vegetable oil based alternate fuels on residue deposits and components wear in a diesel engine," SAE paper 860302, 1986.

[7] F. Karaosmanoğlu, "Vegetable oil fuels: a review," Energy Sources, vol. 21, no. 3, pp. 221-231, 1999.

[8] P. Higelin, Huiles Vegetables - Biocombustible Diesel. Incidence des Aspects Thermiques Lies au Type de Moteur sur la Combustion, University of Orleans, New Orleans, La, USA, 1992.

[9] H. J. Geottler, M. Ziejewski, and A. M. Knudson, "Performance of a diesel engine operating on blends of diesel fuel and crude sunflower oil at normal and elevated fuel temperature," SAE paper 852087, 1985.

[10] A. S. Ramadhas, S. Jayaraj, and C. Muraleedharan, "Use of vegetable oils as I.C. engine fuels-a review," Renewable Energy, vol. 29, no. 5, pp. 727-742, 2004.

[11] O. M. I. Nwafor and G. Rice, "Performance of rapeseed oil blends in a diesel engine," Applied Energy, vol. 54, no. 4, pp. 345-354, 1996.

[12] K. P. McDonnell, S. M. Ward, P. B. McNulty, and R. HowardHildige, "Results of engine and vehicle testing of semirefined rapeseed oil," Transactions of the American Society of Agricultural Engineers, vol. 43, no. 6, pp. 1309-1316, 2000. 
[13] F. Karaosmanoǧlu, G. Kurt, and T. Özaktaş, "Long term CI engine test of sunflower oil," Renewable Energy, vol. 19, no. 1-2, pp. 219-221, 2000.

[14] R. Altin, S. Çetinkaya, and H. S. Yücesu, "Potential of using vegetable oil fuels as fuel for diesel engines," Energy Conversion and Management, vol. 42, no. 5, pp. 529-538, 2001.

[15] G. A. P. Rao and P. R. Mohan, "Effect of supercharging on the performance of a DI diesel engine with cotton seed oil," Energy Conversion and Management, vol. 44, no. 6, pp. 937-944, 2003.

[16] O. M. I. Nwafor, "The effect of elevated fuel inlet temperature on performance of diesel engine running on neat vegetable oil at constant speed conditions," Renewable Energy, vol. 28, no. 2, pp. 171-181, 2003.

[17] Y. He and Y. D. Bao, "Study on cottonseed oil as a partial substitute for diesel oil in fuel for single-cylinder diesel engine," Renewable Energy, vol. 30, no. 5, pp. 805-813, 2005.

[18] Y. D. Wang, T. Al-Shemmeri, P. Eames et al., "An experimental investigation of the performance and gaseous exhaust emissions of a diesel engine using blends of a vegetable oil," Applied Thermal Engineering, vol. 26, no. 14-15, pp. 1684-1691, 2006.

[19] G. Fontaras, A. Mamakos, L. Ntziachristos, G. Miltsios, and Z. Samaras, "Evaluation of cottonseed oil-diesel fuel blends as fuel for automotive diesel engines," in FISITA World Automotive Congress, Yokohama, Japan, 2006.

[20] G. Fontaras, Z. Samaras, and G. Miltsios, "Experimental evaluation of cottonseed oil-diesel blends as automotive fuels via vehicle and engine measurements," SAE Technical Papers, 2007.

[21] S. Mourtzinis, S. Fountas, and T. Gemtos, "Greek farmers' perceptions for precision farming," in Proceedings of the 5th $\mathrm{Na}$ tional Agricultural Engineering Conference, Larissa, Greece, 2007.

[22] A. K. Agarwal and K. Rajamanoharan, "Experimental investigations of performance and emissions of Karanja oil and its blends in a single cylinder agricultural diesel engine," Applied Energy, vol. 86, no. 1, pp. 106-112, 2009.

[23] B. K. Venkanna, C. Venkataramana Reddy, and S. B. Wadawadagi, "Effect of injection pressure on performance, emissions and combustion characteristics of direct injection diesel engine running on blends of pogomia pinnata linn oil (Honge oil) and diesel fuel," Agricultural Engineering International: The CIGR Ejournal, vol. 11, p. 1316, 2009.

[24] Standard Code for the official testing of agricultural and forestry tractor performance. OECD; 2011.

[25] T. Laza and Á. Bereczky, "Basic fuel properties of rapeseed oilhigher alcohols blends," Fuel, vol. 90, no. 2, pp. 803-810, 2011.

[26] L. Geronikolou, Experimental Investigation of Sunflower oil Production from 4 Sunflower Varieties Aiming on Its Use as Diesel Substitute, Agricultural University Athens, Athens, Greece, 2004.

[27] A. Demirbas, "Studies on cottonseed oil biodiesel prepared in non-catalytic SCF conditions," Bioresource Technology, vol. 99, no. 5, pp. 1125-1130, 2008.

[28] A. Demirbaş, "Biodiesel fuels from vegetable oils via catalytic and non-catalytic supercritical alcohol transesterifications and other methods: a survey," Energy Conversion and Management, vol. 44, no. 13, pp. 2093-2109, 2003.

[29] M. Canakci, A. N. Ozsezen, and A. Turkcan, "Combustion analysis of preheated crude sunflower oil in an IDI diesel engine," Biomass and Bioenergy, vol. 33, no. 5, pp. 760-767, 2009.

[30] A. Karmakar, S. Karmakar, and S. Mukherjee, "Properties of various plants and animals feedstocks for biodiesel production," Bioresource Technology, vol. 101, no. 19, pp. 7201-7210, 2010.
[31] K. M. T. Araya, T. Maekawa, and M. Kintayama, "Diesel engine performance with sunflower oil," Journal of Hokkaido College-Senshu University, vol. 20, pp. 137-154, 1987.

[32] R. D. Misra and M. S. Murthy, "Straight vegetable oils usage in a compression ignition engine-a review," Renewable and Sustainable Energy Reviews, vol. 14, no. 9, pp. 3005-3013, 2010.

[33] http://www.carodiesel.com/index/All_About_Biodiesel/Feedstocks/CFPP_Values.htm.

[34] J. M. Desantes, J. Arrègle, S. Ruiz, and A. Delage, "Characterization of the injection-combustion process in a D.I. diesel engine running with rape oil methyl este," SAE paper 1999-011497, 1999.

[35] D. Agarwal and A. K. Agarwal, "Performance and emissions characteristics of Jatropha oil (preheated and blends) in a direct injection compression ignition engine," Applied Thermal Engineering, vol. 27, no. 13, pp. 2314-2323, 2007.

[36] S. Puhan, N. Saravanan, G. Nagarajan, and N. Vedaraman, "Effect of biodiesel unsaturated fatty acid on combustion characteristics of a DI compression ignition engine," Biomass and Bioenergy, vol. 34, no. 8, pp. 1079-1088, 2010.

[37] Fats and Oils. Food Standards Agency, "McCance \& Widdowson's the Composition of Foods," Royal Society of Chemistry, 1991.

[38] S. C. A. de Almeida, C. R. Belchior, M. V. G. Nascimento, L. D. S. R. Vieira, and G. Fleury, "Performance of a diesel generator fuelled with palm oil," Fuel, vol. 81, no. 16, pp. 2097-2102, 2002. 

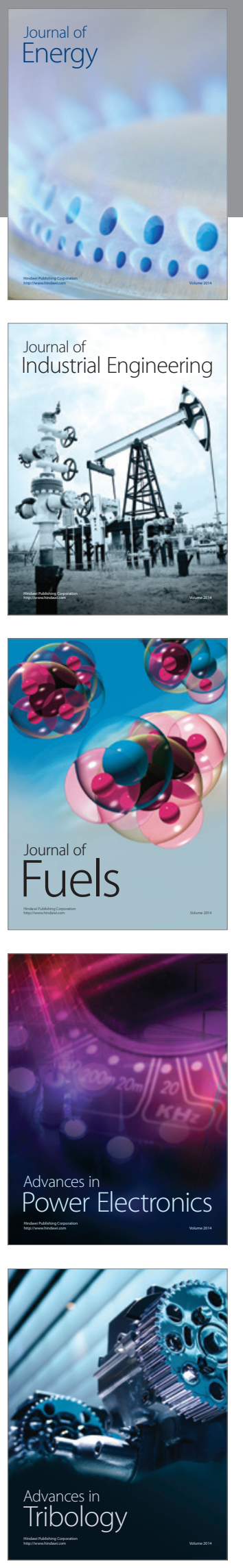
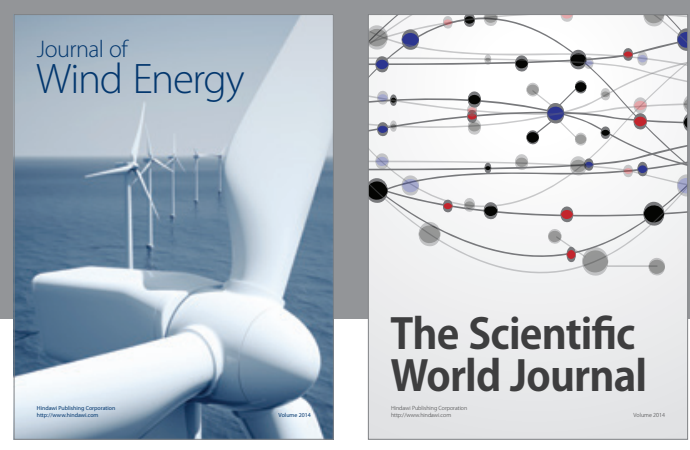

The Scientific World Journal

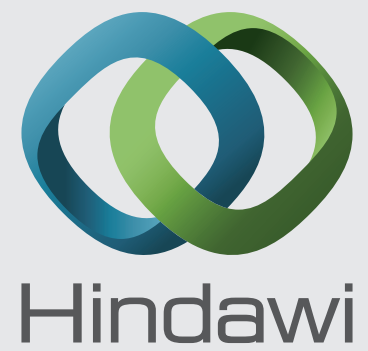

Submit your manuscripts at http://www.hindawi.com
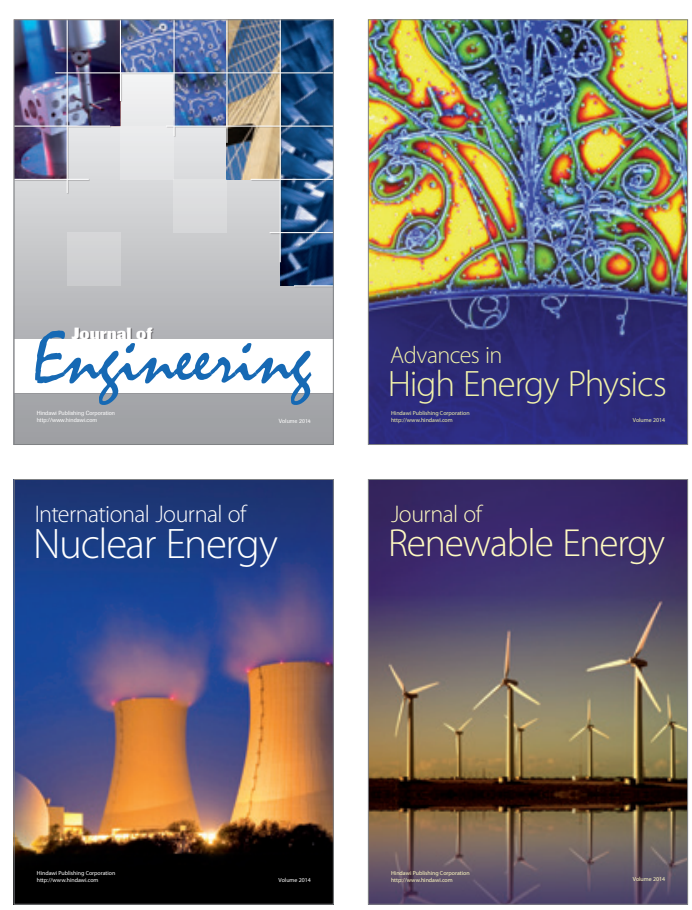

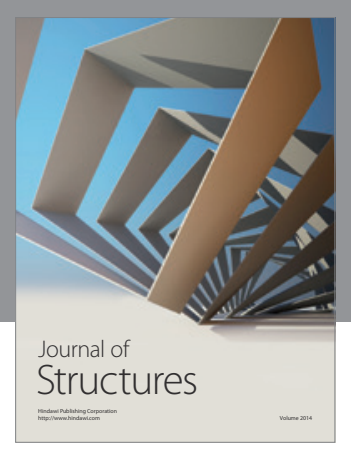

Rotating
Mechinery
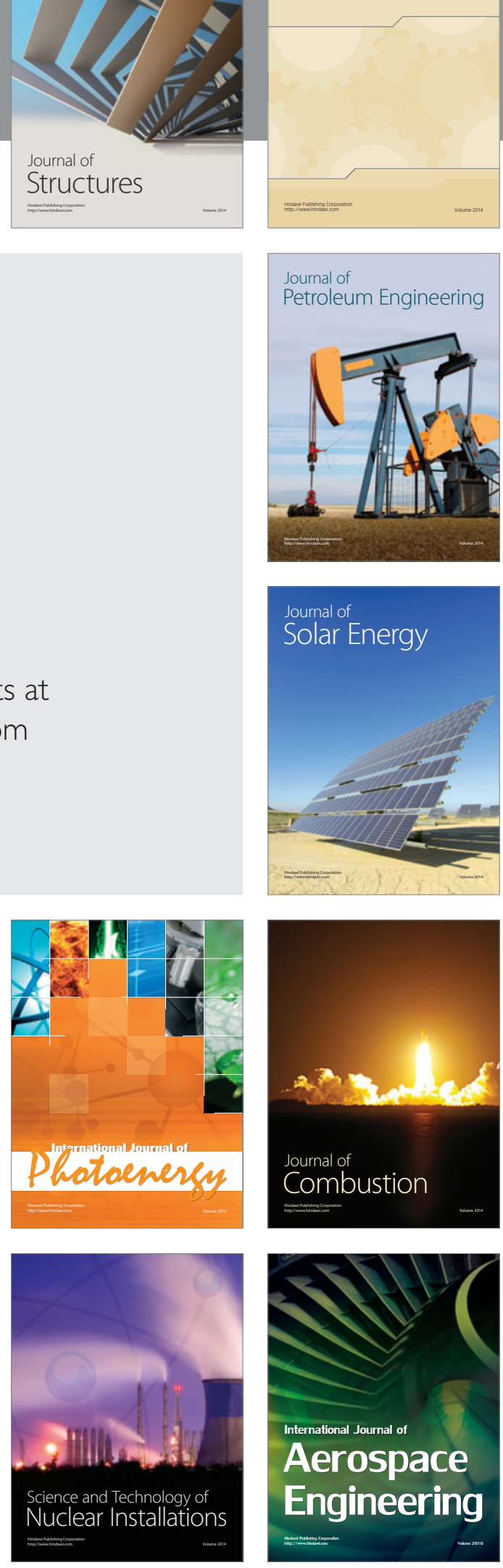